\title{
Role of the oviduct and oviduct-derived products in ruminant embryo development
}

\author{
D. Rizos $^{1,3}$, V. Maillo ${ }^{1}$, P. Lonergan ${ }^{2}$ \\ ${ }^{1}$ Departamento de Reproduccion Animal, Instituto Nacional de Investigacion y Tecnologia Agraria y Alimentaria (INIA), \\ Madrid, Spain. \\ ${ }^{2}$ School of Agriculture and Food Science, University College Dublin, Belfield, Dublin 4, Ireland.
}

\begin{abstract}
The fact that embryos can be obtained in vitro undermines the role of the oviduct. However, it has been demonstrated that when in vitro produced bovine zygotes are cultured in the oviduct of sheep, cattle or mice the embryo quality is improved compared to the embryos produced in vitro. Thus the oviduct is not simply a passive organ required only for transporting the embryo to the uterus but also provides a suitable microenvironment for the early embryo. The study of physiological mechanisms and interactions between the embryo and the oviductal environment is essential to understand the correct processes of early embryo developmental. This knowledge can be used to improve current in vitro procedures providing high quality embryos capable of continued development and implantation, and resulting in viable births.
\end{abstract}

Keywords: bovine, embryo development, in vitro, oviduct.

\section{Introduction}

In vivo, oocytes and embryos develop in a complex and dynamic environment. First, in the ovarian follicle, the oocyte grows and matures, achieving full developmental competence just prior to ovulation. Subsequently, in the oviduct, the oocyte undergoes fertilization and early embryonic development. Finally in the uterus, the blastocyst forms, hatches from the zona pellucida, elongates, and progressively attaches to the uterine wall (Spencer et al., 2007). Therefore, the environment where the early embryo develops has a significant impact on the subsequent embryonic development in the short and long term.

In vitro embryo production seeks to mimic the physiological conditions in which embryos normally develop to produce embryos at the appropriate stage and optimal quality. These characteristics are necessary to establish a pregnancy and to produce a healthy offspring after transfer.

In the last 20 years, researches on in vitro embryo production in ruminants have focused on two crucial questions: how to maximize embryo development and optimize quality of the blastocysts produced. Although a certain amount of progress has been made in both areas, the quality of in vitro produced blastocysts continues to lag behind those obtained in vivo. This inferiority of in vitro produced embryos is manifested in terms of morphology, cryotolerance, gene expression and pregnancy rate after embryo transfer
(Lonergan and Fair, 2008).

It has been demonstrated that the oviductal environment supports embryonic growth up to the blastocyst stage after trans-species transfer across a wide range of species (Fair et al., 2001; Lazzari et al., 2002; Rizos et al., 2007). Using the sheep oviduct in situ for culturing in vitro produced zygotes, it was clearly shown that the key part of the process responsible for suboptimal embryo quality is the postfertilization period (Galli and Lazzari 1996; Enright et al., 2000; Rizos et al., 2002a, b). Thus, studying the oviductal environment and the signals exchanged between the oviduct and/or the early embryo is crucial to improve our understanding of the underlying regulatory mechanisms controlling embryo development (Aviles et al., 2015). Furthermore, this knowledge would allow the development of in vitro models capable to produce embryos of better quality and also to study embryo-maternal interactions. In this review we will discuss the role of the oviductal environment on early embryo development and embryo quality based on evidence from both in vivo and in vitro studies in ruminants.

\section{Role of the oviduct during early embryo development}

The oviduct is a tubular structure, sustained by the mesosalpinx, that connects the ovary to the uterine horn. The oviduct is divided in five morphological and functional parts: (i) the infundibulum, (ii) the ampulla, (iii) the ampullary-isthmic junction, (iv) the isthmus and (v) the utero-tubal junction (Maillo et al., 2016b). The infundibulum is the most proximal structure to the ovary and is funnel-shaped, and its fimbriae receive the oocyte after ovulation. The ampulla is the wider part of the tubal structure. The ampullary-isthmic junction is the place where fertilization takes place (Hunter, 2012). The isthmus presents a narrow lumen and is the place where the sperm reservoir is established prior to fertilization; and also where the early stages of embryo development take place. The utero-tubal junction connects the isthmus to the uterus (Yániz et al., 2000).

The oviduct is an active organ that maintains and modulates the fluidic milieu for sperm capacitation, transport and fertilization of the mature oocyte and early embryonic development (Rodriguez-Martinez, 2007; Leese et al., 2008; Lloyd et al., 2009). After fertilization, the developing embryo passes through the isthmus, through ciliary movements and muscular contractions, until it reaches the uterus about 16-cell stage on day 4 (Ellington, 1991). Therefore, the first 
stages of bovine embryo development occur in the oviduct (Hackett et al., 1993). All these events generate an interest in better understanding the role of the oviduct as a multifunctional and specialized reproductive organ (Rodriguez-Martinez, 2007; Leese et al., 2008).

\section{Oviductal epithelium}

Oviductal epithelium is composed of two different cell types, ciliated and secretory. During gamete and embryo transport, the ciliary cells exhibit a synchronized movement leading to a directed flow of fluids (Abe and Hoshi, 1997). Secretory cells have microvilli on their apical side and secrete substances and growth factors, usually by exocytosis, associated with the first days of the oestrous cycle, which contribute to the development of the early embryo (Abe, 1996; Murray and Smith, 1997).

Sperms transiently adhere to the epithelial cells lining the caudal isthmus, constituting the sperm reservoir. This interaction is important because it lengthens the fertile lifespan of sperm, regulates capacitation and also controls the number of sperm present at the site of fertilization to limit the opportunity for polyspermy (for review, see Miller, 2015)

Populations of the different epithelial cells are dynamic during the phases of the oestrous cycle. The proportion of ciliated cells decreases in the infundibulum and the ampulla during the luteal phase compared with the follicular phase (Yániz et al., 2000). Moreover, cell morphology is modified as a function of embryo development and cycle stage (Suuroia et al. 2002). The height of ciliated cells decreases in the infundibulum and ampulla during the luteal phase and in the isthmus the height of secretory cells also diminishes (Abe et al., 1999). Furthermore, transcriptome approaches have identified different functional groups of genes involved in the regulation of the oviduct during the oestrous cycle (Bauersachs et al., 2004). Recently, Cerny et al. (2015) identified, in bovine oviductal epithelial cells (BOEC), a large number of differentially expressed genes (DEGs) between the follicular (1563 DEGs) and luteal (1758 DEGs) phases, with 616 DEGs exclusive to the ampulla and 811 DEGs exclusive to the isthmus. Similarly, we identified DEGs between the oviductal epithelial cells from the ampulla and isthmus of pregnant heifers collected on day 3 after oestrus. This may reflect morphological and functional differences for those regions (Maillo et al., 2016a).

\section{Oviductal fluid}

Oviductal environment are reflected in the composition of the oviductal fluid (OF). The OF is generated by (i) transudation from plasma into the oviductal lumen together with (ii) the secretion of substances synthesized by the secretory cells (Menezo and Guerin, 1997). OF composition is very complex, containing simple and complex carbohydrates, ions, lipids, phospholipids and proteins (Leese et al., 2001; Avilés et al., 2010). Some of these components are metabolic substrates, such as lactate, pyruvate, amino acids, and glucose, whose concentrations differ from those present in the uterine fluid and serum (Hugentobler et al., 2007, 2008).

Secretions present in the OF affect oocyte and sperm function (Killian, 2011; Mondejar et al., 2013) with proteins such as glycodelins, and lactoferrin involved on gamete interaction (Ghersevich et al., 2015) and oviductin, osteopontins and the complement protein C3 involved in early embryo development (Tse et al., 2008). In addition, these proteins together with others present in the OF have been previously reported to play direct roles in sperm motility, viability (Kouba et al., 2000), sperm-ZP binding (Banerjee and Chowdhury 1994), ZP hardening (Kratz et al., 2003), embryomaternal interactions (Reed et al., 1998), oocyte (Hess et al., 1999), early embryo development (Lim and Hansel 1998), cell proliferation (Hulboy et al., 1997), differentiation and apoptosis, fertilization rates (Dinara et al., 2001), and pH (Ekstedt et al., 2004).

The oviduct-specific glycoprotein (OVGP1) is a component of the OF identified in many species in a highly conserved form. It is one of the most studied proteins in the OF. OVPG1 synthesis and secretion is dynamic and related to oestrogen (Buhi, 2002; Killian, 2004) and luteinizing hormone stimulation (Sun et al., 1997). OVGP1 binds to the zona pellucida (ZP) of the oocyte and early embryo suggesting a role in early embryo development (Buhi, 2002). It has been shown that embryo culture in the presence of oviductin increased embryo development in vivo in pigs (McCauley et al., 2003) and sheep (Pradeep et al., 2011). Coy et al. (2008, 2012) demonstrated that OVGP1 and heparin-like glycosaminoglycans from the oviductal fluid of sows and cows participate in the functional modification of the $\mathrm{ZP}$, affecting the spermoocyte interaction and contributing to the control of polyspermy. Besides, OVGP1 and sperm interactions increased rates of fertilization and embryonic development (Killian, 2004). In addition, it is suggested that OVGP1 stabilizes the microenvironment surrounding by gametes and embryo, preventing dispersal of essential nutrients and ions, particularly during ciliary beating or muscular contraction, increasing the viscosity of luminal fluid (Hunter, 1994; Mondejar et al., 2012).

Proteomic studies of the OF have demonstrated that gametes modulate the oviductal environment in a favourable way to prepare the oviduct milieu for the arrival of the embryo (Georgiou et al., 2005). Sperm regulated twenty proteins, while the oocyte regulated only one protein (Ig kappa light chain). Three proteins were commonly regulated by both gametes (Complement Component C3, Ig kappa variable region, and haemoglobin beta chain), and one protein showed regulation by sperm and oocytes in opposing directions (Complement Component C3; Georgiou et al., 2007).

\section{Embryo-maternal communication in the oviduct}

As mentioned before, after fertilization the first few mitotic cleavage divisions take place in the isthmus 
(Hunter, 1998). On day 3.5 to 4 after fertilization, the early embryo, at the 8- to 16-cell stage, moves from the oviduct to the uterus (Hackett et al., 1993) continuing the mitotic divisions forming first a compact agglomerated of cells called morula and, by day 7 to 8 , a blastocyst.

For a successful pregnancy establishment, a complex signal exchange between the newly formed embryo and the mother is essential. In ruminants, the principal pregnancy-recognition signal produced by the embryo is interferon-tau, secreted by the trophoblast from day 10 up to day 21-25 (Spencer and Bazer, 2004). Alterations in the environment of the early embryo could have consequences in the subsequent development. Thus, a high proportion of embryonic losses occur between days 8 and 17 of pregnancy (Humblot, 2001; Thatcher et al., 2001).

The oviduct, as the first site of embryo development, is considered a starting point to examine putative signals between the embryo and the reproductive tract (Wolf et al., 2003). The embryo in the oviduct undergoes epigenetic changes responsible for further development, implantation and postnatal phenotype (Wrenzycki et al., 2005). However, the mechanisms involved in this embryo-maternal communication currently are mostly unknown (Fazeli, 2008).

Evidence in vivo in mice, by RT-qPCR showed changes in the oviductal gene expression depending on the presence or absence of embryos (Lee et al., 2002). Recently, new transcriptomic technologies (e.g., microarrays) have been used to elucidate the complex molecular dialogue between maternal tract and the embryo. Thus, in pigs Almiñana et al. (2012) showed that embryo-maternal communication exists at earliest stages of pregnancy, before the well-known embryonic signal of maternal recognition. In contrast, Maillo et al. (2015) did not find differences in the bovine oviduct transcriptome in the presence or absence of an 8- to 16-cell embryo in vivo. Obviously, multi-ovulatory species like mice and pigs cannot be directly compared with mono-ovulatory species such as cattle. Thus, the bovine model would provide new information on early embryo maternal communication that may be important for humans.

In this communication, the embryo might play a role as a modulator of the immune system in the maternal tract, inducing the down-regulation of immune related genes to allow the refractory uterus to tolerate the embryo and support its development (Alminana et al., 2012). In a recent study from our group, it was necessary to transfer multiple embryos (up to 50) into the oviducts of heifers to detect differences in the transcriptome. When a single embryo was transferd into the oviduct (pregnant vs cyclic heifers) no differences were found, suggesting a local effect of the embryo (Maillo et al., 2015). More recently, Smits et al. (2016) reported a local influence of the embryo on the transcriptome of the equine oviduct epithelium.

\section{Oviductal environment and in vitro models}

In vitro systems are a valuable tool to study pathways and mechanisms, which are difficult to study in vivo, and cell cultures provide valuable aspects of physiologic or pathologic mechanisms. Studying the oviductal environment is crucial to understand the underlying regulatory mechanisms controlling embryo development (Aviles et al., 2015). The advantages of the oviductal environment have been demonstrated in different models; many physiological aspects have been clarified; however, many others still remain unknown (Hunter, 2012).

The culture of bovine oviductal epithelial cells (BOEC) as a monolayer may provide useful information on early embryo maternal interaction signals. Recently, Schmaltz-Panneau et al. (2014) described transcriptome changes in BOEC related to the presence of bovine embryos. BOEC are usually obtained from oviducts of slaughtered heifers or cows. When a BOEC line is established for in vitro embryo co-culture, it is essential to determine the stage of the oestrous cycle of the oviducts used. BOEC at oestrus have been successfully used as in vitro model simulating embryo maternal interactions (Rief et al., 2002). Recently, Cordova et al. (2014) used oestrus-metoestrus (day 0-3) BOEC for early (day 1-4) or late (day 4-7) embryo co-culture showing that the presence of the cells during the first four days of development, which correspond to the presence of embryos in the oviduct in vivo, accelerated the kinetics of blastocyst development and induced changes in genes involved in epigenetic control. The positive effects of these cells on the embryos are attributed to embryotrophic substances, such as growth factors secreted by the cells (Nancarrow and Hill, 1994; Vanroose et al., 2001). Besides, BOEC modulates the surrounding environmental conditions, decreasing the oxygen levels in the culture medium, preventing the formation of deleterious radicals as reactive oxygen species (ROS; Thompson et al., 2000; Vanroose et al., 2001), removing toxic substances from the medium (e.g., ammonia; Nancarrow and Hill, 1994) and decreasing the glucose and ion levels that could have detrimental effects on the embryos (Vanroose et al., 2001). The drawback of co-culture systems is that they have been associated with methodological complexity, lack of repeatability and biosanitary risk (Menezo and Guerin, 1997). To avoid the use of primary cultures that have a risk of contamination, the use of established cell lines allows standardized culture conditions and better control (Pegoraro et al., 2000). We recently reported that an established BOEC line can be used successfully after freezing and thawing as an in vitro embryo coculture system, avoiding the lack of reproducibility between replicates, and did not differ from BOEC in suspension in terms of embryo development (LoperaVasquez et al., 2016a).

An alternative to co-culture, avoiding a direct contact between BOEC and embryos, is the use of conditioned media from BOEC which has a positive effect on embryo development and percentage live calves after transfer (Lim et al., 1997). The BOEC conditioned media is able to support embryo development to the blastocyst stage (Mermillod et al., 1993) through identified secreted embryotrophic 
components such as OVGP1 (Briton-Jones et al., 2004), ET-1 (Reinhart et al., 2003), IGF (Xia et al., 1996; Winger et al., 1997), VEGF, EGF, IGF1, TGF 32 , and IL4 (Okada et al., 2005). However, many other secretions still remain unknown. Therefore, BOEC coculture and/or their secretions must be a key for studying embryo maternal interactions and improve in vitro current systems.

As mentioned before, the $\mathrm{OF}$ is responsible for nurturing the embryo during the early stages of development. Therefore, using $\mathrm{OF}$ as a supplement during the in vitro embryo culture may affect embryo development and quality. Coy et al. (2008) evaluated the effect of oviductal fluid ( $30 \mathrm{~min}$ incubation) on the ZP of pig and cow oocytes and demonstrated an increase in the proteolytic resistance of the $\mathrm{ZP}$ reflected in a prolonged pronase digestion periods $(3-8 \mathrm{~h})$, and a modulation of sperm-ZP interaction through an increase in monospermy rate. Lloyd et al. (2009) exposed in vitro matured porcine oocytes to bovine OF for $30 \mathrm{~min}$ before fertilization, thereby increasing the blastocyst rate and quality in terms of morphology, cell number, as well as gene expression patterns of apoptotic and developmentally-related genes. Similarly, in cattle, Cebrian-Serrano et al. (2013) evaluated the effect of short-term incubation of matured oocytes with bovine OF; no effect on embryo development was observed but abundance of genes transcripts including G6PD and SOD32 was reported (Cebrian-Serrano et al., 2013). In a recent study, we showed that only low concentrations of OF $(<5 \%)$ in embryo culture media, in the absence of serum, had a positive effect on development and quality in terms of cryotolerance, cell number and expression of qualitatively related genes (Lopera-Vasquez et al., 2015).

The extracellular environment contains a large number of mobile membrane-limited vesicles called "extracellular vesicles" (EVs). EVs contain microvesicles (MVs), apoptotic bodies and exosomes. Originally, the EVs were associated with removal process of receptors and with cellular waste function (Thery, 2011). Subsequently, they were found to have immune effects (Raposo et al., 1996). These data opened the possibility that EVs could play a role in intercellular communication (Thery, 2011). EVs have been found in many biological fluids, including plasma (Caby et al., 2005), serum (Taylor and Gercel-Taylor, 2008), urine (Pisitkun et al., 2004) epididymal fluid (Gatti et al., 2005), amniotic fluid (Asea et al., 2008), follicular fluid (da Silveira et al., 2012), and milk (Admyre et al., 2007). A major discovery was that the content of EVs included both mRNA and miRNA and that EV-associated mRNAs could be translated into proteins by target cells (Valadi et al., 2007). EVs with features of exosomes released by immune cells have been demonstrated to selectively incorporate miRNA that can be functionally transferred as a consequence of fusion with recipient cells (Mittelbrunn et al., 2011).

The possible role of EVs in reproduction has been reported recently. Da Silveira et al. (2012) isolated MVs and exosomes of equine ovarian follicular fluid and, by proteomics and real-time PCR analysis, demonstrated the presence of proteins and miRNAs.
The miRNAs were present in surrounding follicular cells, suggesting that MVs and exosomes play a role in mediating cell communication within the mammalian ovarian follicle (da Silveira et al., 2012). In addition, Sohel et al. (2013) demonstrated the exosome-mediated transport of miRNAs in the bovine follicular microenvironment. Similarly, Ng et al. (2013) identified and examined the presence and potential role of MVs and exosomes in the uterine cavity. MVs and exosomes miRNA has enabled bioinformatic identification of pathways that could be influenced if the exosomes are taken up by trophectoderm or epithelium at the time of implantation, or transferred to sperm as they transit the uterine cavity ( $\mathrm{Ng}$ et al., 2013). The results from Burns et al. (2014) support the hypothesis that exosomes and MVs present in uterine luminal fluid of pregnant and cyclic ewes contain specific proteins, miRNAs, and mRNAs, that are capable of delivering their contents in vitro. Recently, the same group found EVs emanating from both the conceptus trophectoderm and uterine epithelia supporting the notion that MVs in uterine fluid have a biological role in conceptus-endometrial interactions which may be important for the establishment and maintenance of pregnancy (Burns et al., 2016). Al-Dossary et al. (2013) revealed the expression and secretion via oviductal exosomes of PMCA4a (Ca2+ homeostasis) in the female reproductive tissues and luminal fluids during oestrus, and their sperm-uptake, with possible roles in sperm viability during their storage in the oviduct and during capacitation and the acrosome reaction. Recently, the same group have identified oviductosomes (exosomes and microvesicles present in the oviductal fluid) in murine and bovine species although further studies are needed to determine their interaction with gametes/early embryo(s; Al-Dossary and Martin-Deleon, 2016). Furthermore, we provided evidence that extracellular vesicles derived from BOEC-conditioned media improved blastocyst quality and induced cryoprotection in in vitro culture to the same extent as classical coculture with fresh BOEC monolayers (Lopera-Vasquez et al., 2016a). In addition, when extracellular vesicles were obtained from bovine isthmic oviductal fluid and added during the in vitro embryo culture, they had a positive effect on gene expression patterns of developmental-related genes compared with serum supplementation, suggesting an association between the oviductal environment and the developing embryo (Lopera-Vasquez et al., 2016b).

\section{Concluding remarks}

The content of the oviductal environment and its short and long term effects on early embryo development are extremly relevant and may provide new insights on embryo-maternal communication, improving assisted reproductive tecnologies. The challenge today is to develop in vitro culture conditions that will allow growth of the embryo based on the physiological components to which it is exposed in vivo to enhance the development of high/better quality embryos. 


\section{Acknowledgments}

Funded by the Spanish Ministry of Economy and Competitiveness AGL2015-70140-R and by the European Union Seventh Framework Programme FP7/2007-2013 under grant agreement $n^{\circ} 312097$ ('FECUND').

\section{References}

Abe H. 1996 The mammalian oviductal epithelium: regional variations in cytological and functional aspects of the oviductal secretory cells. Histol Histopathol, 11:743-768.

Abe H, Hoshi H. 1997 Bovine oviductal epithelial cells: their cell culture and applications in studies for reproductive biology. Cytotechnology, 23:171-183.

Abe H, Yamashita S, Itoh T, Satoh T, Hoshi H. 1999. Ultrastructure of bovine embryos developed from in vitro-matured and -fertilized oocytes: comparative morphological evaluation of embryos cultured either in serum-free medium or in serum-supplemented medium. Mol Reprod Dev, 53:325-335.

Admyre C, Johansson SM, Qazi KR, Filen JJ, Lahesmaa R, Norman M, Neve EP, Scheynius A, Gabrielsson S. 2007. Exosomes with immune modulatory features are present in human breast milk. $J$ Immunol, 179:1969-1978.

Al-Dossary AA, Strehler EE, Martin-Deleon PA 2013. Expression and secretion of plasma membrane Ca2+-ATPase 4a (PMCA4a) during murine estrus: association with oviductal exosomes and uptake in sperm. PLoS One, 8:e80181.

Al-Dossary, AA, PA Martin-Deleon. 2016. Role of exosomes in the reproductive tract oviductosomes mediate interactions of oviductal secretion with gametes/early embryo. Front Biosci (Landmark Ed), 21:1278-1285.

Almiñana C, Heath PR, Wilkinson S, SanchezOsorio, Cuello JC, Parrilla I, Gil MA, Vazquez JL, Vazquez JM, Roca J, Martinez EA, Fazeli A. 2012. Early developing pig embryos mediate their own environment in the maternal tract. PLoS One, 7:e33625. Asea A, Jean-Pierre C, Kaur P, Rao P, Linhares IM, Skupski D, Witkin SS. 2008. Heat shock proteincontaining exosomes in mid-trimester amniotic fluids. $J$ Reprod Immunol, 79:12-17.

Avilés M, Gutiérrez-Adán A, Coy P. 2010. Oviductal secretions: will they be key factors for the future ARTs? Mol Hum Reprod, 16:896-906.

Aviles M, Coy P, Rizos D. 2015. The oviduct: a key organ for the success of early reproductive events. Anim Front, 5:25-31.

Banerjee M, Chowdhury M. 1994. Purification and characterization of a sperm-binding glycoprotein from human endometrium. Hum Reprod, 9:1497-1504.

Bauersachs S, Rehfeld S, Ulbrich SE, Mallok S, Prelle $\mathbf{K}$, Wenigerkind $\mathbf{H}$, Einspanier R, Blum $\mathbf{H}$, Wolf E. 2004. Monitoring gene expression changes in bovine oviduct epithelial cells during the oestrous cycle. J Mol Endocrinol, 32:449-466.

Briton-Jones C, Lok IH, Cheung CK, Chiu TT,
Cheung LP, C Haines. 2004. Estradiol regulation of oviductin/oviduct-specific glycoprotein messenger ribonucleic acid expression in human oviduct mucosal cells in vitro. Fertil Steril, 81(suppl. 1):749-756.

Buhi WC. 2002 Characterization and biological roles of oviduct-specific, oestrogen-dependent glycoprotein. Reproduction, 123:355-362.

Burns G, Brooks K, Wildung M, Navakanitworakul R, Christenson LK, Spencer TE. 2014. Extracellular vesicles in luminal fluid of the ovine uterus. PLoS One, 9:e90913

Burns GW, Brooks KE, Spencer TE. 2016. Extracellular vesicles originate from the conceptus and uterus during early pregnancy in sheep. Biol Reprod, 94:56.

Caby MP, Lankar D, Vincendeau-Scherrer C, Raposo G, Bonnerot C. 2005. Exosomal-like vesicles are present in human blood plasma. Int Immunol, 17:879-887.

Cebrian-Serrano A, Salvador I, Garcia-Rosello E, Pericuesta E, Perez-Cerezales S, Gutierrez-Adan A, Coy P, Silvestre MA. 2013. Effect of the bovine oviductal fluid on in vitro fertilization, development and gene expression of in vitro-produced bovine blastocysts. Reprod Domest Anim, 48:331-338.

Cerny KL, Garrett E, Walton AJ, Anderson LH, Bridges PJ. 2015. A transcriptomal analysis of bovine oviductal epithelial cells collected during the follicular phase versus the luteal phase of the estrous cycle. Reprod Biol Endocrinol, 13:84.

Cordova A, Perreau C, Uzbekova S, Ponsart C, Locatelli Y, Mermillod P. 2014. Development rate and gene expression of IVP bovine embryos cocultured with bovine oviduct epithelial cells at early or late stage of preimplantation development. Theriogenology, 81:1163-1173.

Coy P, Cánovas S, Mondéjar I, Saavedra MD, Romar R, Grullón L, Matás C, Avilés M. 2008. Oviduct-specific glycoprotein and heparin modulate sperm-zona pellucida interaction during fertilization and contribute to the control of polyspermy. Proc Natl Acad Sci USA, 105:15809-15814.

Coy P, Jimenez-Movilla M, Garcia-Vazquez FA, Mondejar I, Grullon L, Romar R. 2012. Oocytes use the plasminogen-plasmin system to remove supernumerary spermatozoa. Hum Reprod, 27:19851993.

da Silveira JC, Veeramachaneni DN, Winger QA, Carnevale EM, Bouma GJ. 2012. Cell-secreted vesicles in equine ovarian follicular fluid contain miRNAs and proteins: a possible new form of cell communication within the ovarian follicle. Biol Reprod, $86: 71$

Dinara S, Sengoku K, Tamate K, Horikawa M, Ishikawa M. 2001. Effects of supplementation with free radical scavengers on the survival and fertilization rates of mouse cryopreserved oocytes. Hum Reprod, 16:1976-1981

Ekstedt E, Holm L, Ridderstrale Y. 2004. Carbonic anhydrase in mouse testis and epididymis; transfer of isozyme IV to spermatozoa during passage. $\mathrm{J} \mathrm{Mol}$ Histol, 35:167-173. 
Ellington JE. 1991. The bovine oviduct and its role in reproduction: a review of the literature. Cornell Vet, 81:313-328.

Enright BP, Lonergan P, Dinnyes A, Fair T, Ward FA, Yang X, Boland MP. 2000. Culture of in vitro produced bovine zygotes in vitro vs in vivo: implications for early embryo development and quality. Theriogenology, 54:659-673.

Fair T, Lonergan P, Dinnyes A, Cottell DC, Hyttel P, Ward FA, Boland MP. 2001. Ultrastructure of bovine blastocysts following cryopreservation: effect of method of blastocyst production. Mol Reprod Dev, 58:186-195.

Fazeli A. 2008. Maternal communication with gametes and embryos. Theriogenology, 70:1182-1187.

Galli C, Lazzari G. 1996. Practical aspects of IVM/IVF in cattle. Anim Reprod Sci, 42:371-379.

Gatti JL, Metayer S, Belghazi M, Dacheux F, Dacheux JL. 2005. Identification, proteomic profiling, and origin of ram epididymal fluid exosome-like vesicles. Biol Reprod, 72:1452-1465.

Georgiou AS, Sostaric E, Wong CH, Snijders AP, Wright PC, Moore HD, Fazeli A. 2005. Gametes alter the oviductal secretory proteome. Mol Cell Proteomics, 4:1785-1796.

Georgiou AS, Snijders AP, Sostaric E, Aflatoonian R, Vazquez JL, Vazquez JM, Roca J, Martinez EA, Wright PC, Fazeli A. 2007. Modulation of the oviductal environment by gametes. J Proteome Res, 6:4656-4666.

Ghersevich S, Massa E, Zumoffen C. 2015. Oviductal secretion and gamete interaction. Reproduction, 149:r1r14.

Hackett A, Durnford R, Mapletoft R, Marcus G 1993. Location and status of embryos in the genital tract of superovulated cows 4 to 6 days after insemination. Theriogenology, 40:1147-1153.

Hess KA, Chen L, Larsen WJ. 1999. Inter-alphainhibitor binding to hyaluronan in the cumulus extracellular matrix is required for optimal ovulation and development of mouse oocytes. Biol Reprod, 61:436-443.

Hugentobler SA, Diskin MG, Leese HJ, Humpherson PG, Watson T, Sreenan JM, Morris DG. 2007. Amino acids in oviduct and uterine fluid and blood plasma during the estrous cycle in the bovine. Mol Reprod Dev, 74:445-454.

Hugentobler SA Humpherson, PG, Leese HJ, Sreenan JM, Morris DG. 2008. Energy substrates in bovine oviduct and uterine fluid and blood plasma during the oestrous cycle. Mol Reprod Dev, 75:496-503. Hulboy DL, Rudolph LA, Matrisian LM. 1997. Matrix metalloproteinases as mediators of reproductive function. Mol Hum Reprod, 3:27-45.

Humblot P. 2001. Use of pregnancy specific proteins and p4 assays to monitor pregnancy. Theriogenology, 56:1417-1433.

Hunter RH. 1994. Modulation of gamete and embryonic microenvironments by oviduct glycoproteins. Mol Reprod Dev, 39:176-181.

Hunter RH. 1998. Have the Fallopian tubes a vital rôle in promoting fertility? Acta Obstet Gynecol Scand, $77: 475-486$.
Hunter RH. 2012 Components of oviduct physiology in eutherian mammals. Biol Rev Camb Philos Soc, 87:244-255.

Killian G. 2004. Evidence for the role of oviduct secretions in sperm function, fertilization and embryo development. Anim Reprod Sci, 82/83:141-153.

Killian G. 2011. Physiology and endocrinology symposium: evidence that oviduct secretions influence sperm function: a retrospective view for livestock. $J$ Anim Sci, 89:1315-1322.

Kouba AJ, Abeydeera LR, Alvarez IM, Day BN, Buhi WC. 2000. Effects of the porcine oviduct-specific glycoprotein on fertilization, polyspermy, and embryonic development in vitro. Biol Reprod, 63:242250.

Kratz E, Poland DC, van Dijk W, KatnikPrastowska I. 2003. Alterations of branching and differential expression of sialic acid on alpha-1-acid glycoprotein in human seminal plasma. Clin Chim Acta, 331:87-95.

Lazzari G, Wrenzycki C, Herrmann D, Duchi R, Kruip T, Niemann H, Galli C. 2002. Cellular and molecular deviations in bovine in vitro-produced embryos are related to the large offspring syndrome. Biol Reprod, 67:767-775.

Lee KF, Yao YQ, Kwok KL, Xu JS, Yeung WS. 2002. Early developing embryos affect the gene expression patterns in the mouse oviduct. Biochem Biophys Res Commun, 292:564-570.

Leese HJ, Tay JI, Reischl J, Downing SJ. 2001. Formation of Fallopian tubal fluid: role of a neglected epithelium. Reproduction, 121:339-346.

Leese HJ, Hugentobler SA, Gray SM, Morris DG, Sturmey RG, Whitear SL, Sreenan JM. 2008. Female reproductive tract fluids: composition, mechanism of formation and potential role in the developmental origins of health and disease. Reprod Fertil Dev, 20:1-8. Lim JM, Reggio BC, Godke RA, Hansel W. 1997. Perifusion culture system for bovine embryos: improvement of embryo development by use of bovine oviduct epithelial cells, an antioxidant and polyvinyl alcohol. Reprod Fertil Dev, 9:411-418.

Lim JM, Hansel W. 1998. Improved development of in vitro-derived bovine embryos by use of a nitric oxide scavenger in a cumulus-granulosa cell coculture system. Mol Reprod Dev, 50:45-53.

Lloyd RE, Romar R, Matás C, Gutiérrez-Adán A, Holt WV, Coy P. 2009. Effects of oviductal fluid on the development, quality, and gene expression of porcine blastocysts produced in vitro. Reproduction, 137:679-687.

Lonergan P, Fair T. 2008. In vitro-produced bovine embryos: dealing with the warts. Theriogenology, 69:17-22

Lopera-Vasquez R, Hamdi M, Maillo V, Lloreda V, Coy P, Gutierrez-Adan A, Bermejo-Alvarez P, Rizos D. 2015. Effect of bovine oviductal fluid on development and quality of bovine embryos produced in vitro. Reprod Fertil Dev. doi: 10.1071/RD15238.

Lopera-Vasquez R, Hamdi M, Fernandez-Fuertes B, Maillo V, Beltran-Brena $P$, Calle A, Redruello A, Lopez-Martin S, Gutierrez-Adan A, Yanez-Mo M, 
Ramirez MA, Rizos D. 2016a. Extracellular vesicles from BOEC in in vitro embryo development and quality. PLoS One, 11:e0148083.

Lopera-Vasquez R, Hamdi M, Maillo V, Nunez C, Yanez-Mo M, Ramirez M, Gutierrez-Adan A, Bermejo-Alvarez P, Rizos D. 2016b. Vesicles of bovine oviductal fluid modify the gene expression on bovine in vitro derived embryos. Reprod Fertil Dev, 28:179.

Maillo V, Gaora PO, Forde N, Besenfelder U, Havlicek V, Burns GW, Spencer TE, GutierrezAdan A, Lonergan P, Rizos D. 2015. Oviduct-embryo interactions in cattle: two-way traffic or a one-way street? Biol Reprod, 92:144.

Maillo V, de Frutos C, O'Gaora P, Forde N, Burns GW, Spencer TE, Gutierrez-Adan A, Lonergan P, Rizos D. 2016a. Spatial differences in gene expression in the bovine oviduct. Reproduction, 152:37-46.

Maillo V, Lopera-Vasquez, Hamdi RM, GutierrezAdan A, Lonergan P, Rizos D. 2016b. Maternalembryo interaction in the bovine oviduct: evidence from in vivo and in vitro studies. Theriogenology, 86:443450.

McCauley TC, Buhi WC, Wu GM, Mao J, Caamano JN, Didion BA, Day BN. 2003. Oviduct-specific glycoprotein modulates sperm-zona binding and improves efficiency of porcine fertilization in vitro. Biol Reprod, 69:828-834.

Menezo Y, P Guerin. 1997. The mammalian oviduct: biochemistry and physiology. Eur J Obstet Gynecol Reprod Biol, 73:99-104.

Mermillod P, Vansteenbrugge A, Wils C, Mourmeaux JL, Massip A, Dessy F. 1993. Characterization of the embryotrophic activity of exogenous protein-free oviduct-conditioned medium used in culture of cattle embryos. Biol Reprod, 49:582587.

Miller DJ. 2015. Regulation of sperm function by oviduct fluid and the epithelium: insight into the role of glycans. Reprod Domest Anim, 50(suppl. S2):31-39.

Mittelbrunn M, Gutierrez-Vazquez C, VillarroyaBeltri, Gonzalez CS, Sanchez-Cabo F, Gonzalez MA, Bernad A, Sanchez-Madrid F. 2011. Unidirectional transfer of microRNA-loaded exosomes from T cells to antigen-presenting cells. Nat Commun, 2:282.

Mondejar I, Grullon LA, Garcia-Vazquez FA, Romar R, Coy P. 2012. Fertilization outcome could be regulated by binding of oviductal plasminogen to oocytes and by releasing of plasminogen activators during interplay between gametes. Fertil Steril, 97:453461 .

Mondejar I, Martinez-Martinez I, Aviles M, Coy P. 2013. Identification of potential oviductal factors responsible for zona pellucida hardening and monospermy during fertilization in mammals. Biol Reprod, 89:1-8.

Murray SC, Smith TT. 1997. Sperm interaction with fallopian tube apical membrane enhances sperm motility and delays capacitation. Fertil Steril, 68:351-357.

Nancarrow CD, Hill JL. 1994. Co-culture, oviduct secretion and the function of oviduct-specific glycoproteins. Cell Biol Int, 18:105-1114.
Ng YH, Rome S, Jalabert A, Forterre A, Singh H, Hincks CL, Salamonsen LA. 2013. Endometrial exosomes/microvesicles in the uterine microenvironment: a new paradigm for embryoendometrial cross talk at implantation. PLoS One, 8:e58502

Okada H, Hirose Y, Manonmani P, Uda A, Ito M, Sankai T. 2005. Characterization of an immortalized oviduct cell line from the cynomolgus monkey (Macaca fascicularis). J Med Primatol, 34:67-72.

Pegoraro LM, Thuard JM, Delalleau N, Guerin B, Deschamps JC, Marquant Le Guienne B, Humblot P. 2000. Comparison of sex ratio and cell number of IVM-IVF bovine blastocysts co-cultured with bovine oviduct epithelial cells or with Vero cells. Theriogenology, 49:1579-1590.

Pisitkun T, Shen RF, Knepper MA. 2004. Identification and proteomic profiling of exosomes in human urine. Proc Natl Acad Sci USA, 101:1336813373.

Pradeep MA, Jagadeesh J, De AK, Kaushik JK, Malakar D, Kumar S, Dang AK, Das SK, Mohanty AK. 2011. Purification, sequence characterization and effect of goat oviduct-specific glycoprotein on in vitro embryo development. Theriogenology, 75:1005-1015.

Raposo G, Nijman HW, Stoorvogel W, Liejendekker R, Harding CV, Melief CJ, Geuze HJ. 1996. B lymphocytes secrete antigen-presenting vesicles. $J$ Exp Med, 183:1161-1172.

Reed KL, Blaeser LL, Dantzer V, Green ML, Simmen RC. 1998. Control of secretory leukocyte protease inhibitor gene expression in the porcine periimplantation endometrium: a case of maternalembryo communication. Biol Reprod, 58:448-457.

Reinhart KC, Dubey RK, Cometti B, Keller PJ, Rosselli M. 2003. Differential effects of natural and environmental estrogens on endothelin synthesis in bovine oviduct cells. Biol Reprod, 68:1430-1436.

Rief S, Sinowatz F, Stojkovic M, Einspanier R, Wolf E, Prelle K. 2002. Effects of a novel co-culture system on development, metabolism and gene expression of bovine embryos produced in vitro. Reproduction, 124:543-556.

Rizos D, Lonergan P, Boland MP, Arroyo-García R, Pintado B, de la Fuente J, Gutiérrez-Adán A. 2002a. Analysis of differential messenger RNA expression between bovine blastocysts produced in different culture systems: implications for blastocyst quality. Biol Reprod, 66: 589-595

Rizos D, Ward F, Duffy P, Boland MP, Lonergan P. 2002 b. Consequences of bovine oocyte maturation, fertilization or early embryo development in vitro versus in vivo: implications for blastocyst yield and blastocyst quality. Mol Reprod Dev, 61:234-248.

Rizos D, Pintado B, de la Fuente J, Lonergan P, Gutiérrez-Adán A. 2007. Development and pattern of mRNA relative abundance of bovine embryos cultured in the isolated mouse oviduct in organ culture. Mol Reprod Dev, 74:716-723.

Rodriguez-Martinez H. 2007. Role of the oviduct in sperm capacitation. Theriogenology, 68(suppl. 1):S138146. 
Schmaltz-Panneau B, Cordova A, Dhorne-Pollet S, Hennequet-Antier C, Uzbekova S, Martinot E, Doret S, Martin P, Mermillod P, Locatelli Y. 2014. Early bovine embryos regulate oviduct epithelial cell gene expression during in vitro co-culture. Anim Reprod Sci, 149:103-116.

Smits K, De Coninck DI, Van Nieuwerburgh F, Govaere J, Van Poucke M, Peelman L, Deforce D, Van Soom A. 2016. The equine embryo influences immune-related gene expression in the oviduct. Biol Reprod, 94:36.

Sohel MM, Hoelker M, Noferesti SS, SalilewWondim D, Tholen E, Looft C, Rings F, Uddin MJ, Spencer TE, Schellander K, Tesfaye D. 2013. Exosomal and non-exosomal transport of extra-cellular microRNAs in follicular fluid: implications for bovine oocyte developmental competence. PLoS One, 8:e78505.

Spencer TE, Bazer FW. 2004. Conceptus signals for establishment and maintenance of pregnancy. Reprod Biol Endocrinol, 2:49.

Spencer TE, Johnson GA, Bazer FW, Burghardt RC, Palmarini M. 2007. Pregnancy recognition and conceptus implantation in domestic ruminants: roles of progesterone, interferons and endogenous retroviruses. Reprod Fertil Dev, 19:65-78.

Sun T, Lei ZM, Rao CV. 1997. A novel regulation of the oviductal glycoprotein gene expression by luteinizing hormone in bovine tubal epithelial cells. Mol Cell Endocrinol, 131:97-108.

Suuroia T, Aunapuu M, Arend A, Sepp E. 2002. "Light" epithelial cells of swine and bovine oviducts [in Russian]. Tsitologiia, 44:656-660.

Taylor DD, Gercel-Taylor C. 2008. MicroRNA signatures of tumor-derived exosomes as diagnostic biomarkers of ovarian cancer. Gynecol Oncol, 110:13-21.

Thatcher WW, Guzeloglu A, Mattos R, Binelli M, Hansen TR, Pru JK. 2001. Uterine-conceptus interactions and reproductive failure in cattle. Theriogenology, 56:1435-1450.

Thery C. 2011. Exosomes: secreted vesicles and intercellular communications. F1000 Biol Rep, 3:15.
Thompson JG, McNaughton C, Gasparrini B, McGowan LT, Tervit HR. 2000. Effect of inhibitors and uncouplers of oxidative phosphorylation during compaction and blastulation of bovine embryos cultured in vitro. J Reprod Fertil, 118:47-55.

Tse PK, Lee YL, Chow WN, Luk JM, Lee KF, Yeung WS. 2008. Preimplantation embryos cooperate with oviductal cells to produce embryotrophic inactivated complement-3b. Endocrinology, 149:12681276.

Valadi H, Ekstrom K, Bossios A, Sjostrand M, JJ Lee, Lotvall JO. 2007. Exosome-mediated transfer of mRNAs and microRNAs is a novel mechanism of genetic exchange between cells. Nat Cell Biol, 9:654659.

Vanroose G, Van Soom A, de Kruif A. 2001. From co-culture to defined medium: state of the art and practical considerations. Reprod Domest Anim, 36:2528.

Winger QA, P de los Rios, Han VK, Armstrong DT, Hill DJ, Watson AJ. 1997 Bovine oviductal and embryonic insulin-like growth factor binding proteins: possible regulators of "embryotrophic" insulin-like growth factor circuits. Biol Reprod, 56:1415-1423.

Wolf E, Arnold GJ, Bauersachs S, Beier HM, Blum H, Einspanier R, T Fröhlich, Herrler A, Hiendleder S, Kölle S, K Prelle, Reichenbach HD, Stojkovic M, Wenigerkind H, Sinowatz F. 2003 Embryo-maternal communication in bovine - strategies for deciphering a complex cross-talk. Reprod Domest Anim, 38:276-289.

Wrenzycki C, Herrmann D, Lucas-Hahn A, Korsawe K, Lemme E, Niemann H. 2005. Messenger RNA expression patterns in bovine embryos derived from in vitro procedures and their implications for development. Reprod Fertil Dev, 17:23-35.

Xia P, Han VK, Viuff D, Armstrong DT, Watson AJ. 1996. Expression of insulin-like growth factors in two bovine oviductal cultures employed for embryo coculture. J Endocrinol, 149:41-53.

Yániz JL, Lopez-Gatius F, Santolaria P, Mullins KJ. 2000. Study of the functional anatomy of bovine oviductal mucosa. Anat Rec, 260:268-278. 